\title{
Impact of Basel II on Bank Portfolios in Australia
}

\author{
Dr. Muhammad Saifuddin Khan ${ }^{1 *} \quad$ Dr. Md. Shahidul Islam ${ }^{2}$ \\ 1. Assistant Professor, Department of Finance, University of Dhaka, Dhaka-1000, Bangladesh \\ 2.Associate Professor, Department of Banking and Insurance, University of Dhaka, Dhaka-1000, Bangladesh
}

\begin{abstract}
This paper analyses the sensitivity of various risk-weighted assets and liabilities to regulatory capital ratios of domestic and foreign banks in Australia. In particular, this paper investigates whether the growth of various riskweighted assets changes during the post-Basel II period and whether those changes are caused by the more rigorous capital regulation introduced by the Basel II. The empirical analysis shows that Australian local banks is found to experience a substantial increase of the high-risk weighted assets (namely, non-residential loans) and subordinated debt with respect to their tier 1 capital ratio. The same changes, however, are found to have insignificant influence on the growth of low-risk weighted assets and total asset.
\end{abstract}

Keywords: Regulatory capital; Basel II; Bank; Australia

DOI: $10.7176 / \mathrm{EJBM} / 11-5-04$

\section{Introduction}

Banks have an incentive to alter their asset portfolios from high-risk weighted assets to low-risk weighted assets in order to comply with the more rigorous risk-weighted capital regulation. This paper analyses the sensitivity of various risk-weighted assets and liabilities of domestic and foreign banks in Australia to regulatory capital ratios (Total Capital Ratio and Tier 1 Capital Ratio). In particular, this paper investigates whether the growth of various risk-weighted assets changes during the post-Basel II period and whether those changes are caused by the more rigorous capital regulation introduced by the Basel II. The empirical analysis shows the following findings with respect to the regulatory changes of Basel II. First, Australian local banks is found to experience a substantial increase of the high-risk weighted assets (namely, non-residential loans) and subordinated debt with respect to their tier 1 capital ratio. The same changes, however, are found to have insignificant influence on the growth of low-risk weighted assets and total asset. This paper rejects the capital crunch hypothesis and credit crunch hypothesis because the stricter capital regulations associated with Basel II do not induce Australian banks to reduce their assets and loans. Hence, this paper rejects the idea that more rigorous capital regulation induces Australian banks to reallocate their asset portfolio from high-risk weighted assets to low-risk weighted assets.

Australian banks are financially healthy and maintain sound capital. They are well-capitalized with a resistant funding base (Hawtrey, 2009). In addition, Australian banks were not affected by the recent global financial crisis and no Australian banks were required to bail out and/or write-down loans abnormally during the global financial crisis supported by the study of Hawthery (2009). Therefore, the general wisdom suggests that Australian banks may not be affected by changes in the capital regulation.

- The changes in regulation affect the risk-based capital ratios, which eventually require the banks to adjust their portfolio. A capital-constrained bank can recover capital ratio either by reducing assets or by increasing equity capital (Hyun and Rhee, 2011)). Raising equity capital is not at all costless, in particular, when information asymmetry exists between investors and banks(Myers and Majluf, 1984). Research also shows that the market for bank equity is imperfect and the presence of agency costs and tax disadvantages interrupts the issuing new equity of banks (Gambacorta and Mistrulli, 2004)). Consequently banks are obliged to maintain the regulatory capital in association with credit supply (Gambacorta and Mistrulli, 2004). This means that banks may have to shrink their loan supply for maintaining the regulatory capital (Watanabe, 2007) and accordingly, they have to adjust their portfolio decisions. Taking this view, this paper investigates the effect of risk-based capital ratios, introduced by Bank for International Settlements (hereafter, BIS), on bank portfolio decisions of Australian banks. In other words, are the adjustments of asset portfolios, if any, of Australian banks accompanied by the implementation of more rigorous capital adequacy requirements introduced by Basel II?

While Australian banks rarely needed to raise equity for maintaining the lending supply as a result of the implementation of Basel II (Hawtrey, 2009), the stricter capital standard imposed under Basel II may force banks to shrink their assets, a phenomenon described as capital crunch hypothesis (Peek and Rosengren, 1995b). Several studies provide empirical support of the capital crunch hypothesis followed by capital regulation introduced by Basel I (Hall, 1993, Brinkmann and Horvitz, 1995a, Peek and Rosengren, 1995b). Empirical and theoretical studies find the linkage between capital crunch and credit crunch (Peek and Rosengren, 1995b, Berger and Udell, 1994, Brinkmann and Horvitz, 1995b), the latter being the outcome of the former due to capital regulation (Peek and Rosengren, 1995a). 
Not surprisingly, the stricter regulations not only induce the banks to shrink their assets and loans but also increase low-risk weighted assets. Prior empirical studies including (Hall, 1993, Brinkmann and Horvitz, 1995a, Berger and Udell, 1994, Peek and Rosengren, 1995a)) support this argument. They find that the regulatory changes brought about by Basel I caused U.S. banks to reduce lending in high-risk assets and thus Basel I is recognized as a cause of credit crunch. Similar consequences are also experienced by Japanese (Ito and Sasaki, 2002, Watanabe, 2007, Brana and Lahet, 2009). The only exception is the study of Horiuchi and Shimizu (1998), who rather find that the implementation of Basel I induce the capital-constrained banks of Japan to increase their loan supply more swiftly albeit for the short-term only. Recent studies including (Hyun and Rhee, 2011, Jacques, 2008, Memmel and Raupach, 2010) and Hyun \& Rhee (2011) find that the capital regulation introduced by Basel II also influence banks to reduce total risk-weighted assets by adjusting asset portfolio. While there are few researches which study the impact of capital regulations on Australian banks, no prior research addressed the impact of the changes of capital regulation made by Basel II on the Australian banks' loan supply and asset portfolio choice. This paper attempts to fill that gap.

Basel II, which was implemented in Australia on January 2008, imposes more rigorous capital adequacy requirement than Basel I. As noted earlier, in response to Basel II, a bank can raise its capital ratio either by increasing capital or by reducing risk-weighted assets. It also suggests that capital can be increased by issuing new equities, subordinated debt, and preferred stock or by increasing loan loss reserves up to a maximum of $1.25 \%$ of risk-weighted assets. Risk-weighted assets can be reduced by rebalancing the asset portfolio, which can be achieved by replacing high risk-weighted assets such as loans or equity holdings with low risk-weighted assets such as government bonds and mortgages. A related question is have the growth of various risky assets been affected by the changes of capital regulation come with Basel II (Research Question 1)? And if so, is the growth of various risky assets different in the pre- and post-Basel II period (Research Question 2)? In order to answer these research questions, we use the Balance sheet data for the period of 2000-2010 from 14 local and 8 foreign banks operating in Australia. We expect that the analysis would enable one to gauge the sensitivity of various riskweighted assets and liabilities to regulatory capital ratios (Total Capital Ratio and Tier 1 Capital Ratio). The data are collected from Bankscope.

Our empirical analysis indicates the following set of findings. First, we find that local banks of Australia face higher growth of non-residential loans in the post-Basel II period and the growth of that is affected by the regulatory changes caused by Basel II. Second, Basel II affects the higher growth of subordinated debt in the postBasel II period. Third, Basel II does not affect the growth of total assets and low-risk assets.

The remainder of the paper is structured as follows. Section two describes motivation and research objective followed by literature review and hypotheses in Section three. Data and methodology are described in Section four, while Section five presents the empirical findings including followed by robustness check in Section six. Section seven highlights the limitation and further research implications followed by a conclusion in Section eight.

\section{Motivation and Research Objective}

Basel II introduces more rigorous capital regulation than Basel I. Therefore, Basel II may cause Australia banks to alter their asset portfolios from high-risk assets to low-risk assets. That is, Basel II requires that Australian banks revise their asset portfolios from heavily risk-weighted assets such as loans and equity investments to low riskweighted assets such as mortgages and government securities. The issue is very important and so far there is no evidence of this issue in the Australian context. The motivation of this paper is to examine the relationship between the introduction of Basel II and the asset portfolio decision of Australian banks.

Another objective of this research is to identify whether the sensitivity of risk-based capital ratios to the asset holdings is different in the pre-Basel II and post-Basel II period. It also tries to identify whether the asset holdings contract or expand due to the implementation of Basel II and whether banks issue equity or subordinated debt to maintain the risk-adjusted capital ratio. Thus, the analysis covers the effect of capital regulation on the growth of both assets and liabilities.

\section{Literature Review and Hypothesis Development}

The prior literature includes numerous studies of how the Basel agreements may have affected banks' asset portfolio. Literature review is divided into three subsections on the basis of Basel I, II and III. Due to the difference between sample periods and financial markets examined, different researches found banks adjusting their asset portfolios differently in response to different capital regulations. This is highlighted in the following sub-sections.

\subsection{Basel I}

As issuing capital is more expensive than collecting deposits, risk-based capital may be viewed as a regulatory tax that is higher on assets, which are assigned higher risk weights. Therefore, it was expected that implementation of risk-based capital under Basel I would encourage banks to substitute out of high-risk weighted assets and into lowrisk weighted assets. Montgomery (2005) tries to find whether banks adjust their asset portfolios by reducing high- 
risk weighted assets and increasing low-risk weighted assets due to the stricter capital adequacy requirement introduced under Basel I. During the post-Basel I period, international banks in Japan with relatively low core capital ratios are likely to contract their overall assets and reallocate their asset portfolio from heavily-weighted risky assets, such as loans and corporate bonds, to zero-weighted riskless assets such as government bonds (Montgomery, 2005). International banks in Japan issue more subordinated debt in the post-Basel I period (Montgomery, 2005). Again, Basel I induces U.S. commercial banks to shift away from high-risk assets such as loans towards low-risk assets such as government securities and the portfolio shift triggers the substantial reduction in bank lending (Hall, 1993). As a result, Basel I has been considered as one of the major causes of the credit crunch (Hall, 1993). Similarly, Brikmann and Horvitz (1995) find that Basel I creates U.S. bankers reluctant to lend. Berger and Udell (1994) also find that Basel I compels U.S. banks to reduce commercial loans and increase holdings of government securities. Hogan and Sharpe (1990) analyse the initial application of Basel I to three major Australian banks named Australia and New Zealand Banking Group, National Australia Bank Ltd. and Westpac Banking Corporation. The risk-adjusted capital ratio introduced by Basel I is partial in coverage because it considers default risk only and might distort the allocation of credit (Hogan and Sharpe, 1990).

The risk-based capital standard significantly influences the behaviour of Japanese banks and capitalconstrained banks are likely to issue more subordinated debts and to reduce lending (Ito and Sasaki, 2002). Similarly, Watanabe (2007) finds that a huge loss of bank capital caused Japanese banks to reduce their lending in the fiscal year of 1997. Because capital loss of banks was occurred as a result of a rigorous self-assessment of assets requested by the regulator(Watanabe, 2007). But loan supply increased as a result of an injection of public capital in fiscal year 1998 which relaxes the capital constraint of banks (Watanabe, 2007).

Capital regulation may lead to financial crisis and capital injection by the government. Brana and Lahet (2009) also suggest that the implementation of risk-based capital ratio under Basel I has significantly affected Japanese banking behaviour and is one of the factors that triggers the 1997 Asian crisis. As a result of the enhancement of capital requirement, Japanese banks issue new equities and subordinated debts (Brana and Lahet, 2009). Japanese banks also cut back their risky assets, especially their foreign assets, as a result of long-lasting stock price fall and growing troubles in the banking system since 1990 (Brana and Lahet, 2009).

The monetary policy affects the shrinkage of assets and loans triggered by capital regulation. As a result of a contractionary monetary policy in the post-Basel I period, the loans of the small low-capital banks are reduced more than that of high-capital banks (Kishan and Opiela, 2006). However, the loan growth of the low-capital banks is not higher compared to that of high capital banks as a result of an expansionary monetary policy (Kishan and Opiela, 2006). Also, the lending of high-capital banks is not affected by contractionary monetary policy, but expansionary policy induces the small high-capital banks to increase loan growth (Kishan and Opiela, 2006). Again, Peek and Rosengren (1995a) identify that capital regulation contracts both bank loan portfolios and bank lending. As a result of capital regulation bank-dependent loans contract to a large extent, and this contraction is both statistically and economically significant (Peek and Rosengren, 1995a).

In contrast, few studies reject the idea that stricter capital regulation causes banks to shrink their assets and loan supply. Horiuchi and Shimizu (1998) reject the capital crunch hypothesis and find that Japanese banks with lower capital-to-asset ratios are likely to increase their credit supply at a faster rate. Rather an increase in banks' equity capital makes banks more conservative to expand credit supply and banks issue subordinated debts to maintain the capital ratio which is a key factor for the absence of capital crunch (Horiuchi and Shimizu, 1998).On the other hand, Beatty and Gron (2001) find no systematic differences between pre- and post-Basel I period behaviour of U.S. banks. However, significant differences exist between low-capital banks and other banks(Beatty and Gron, 2001). The low-capital banks increase equity significantly greater than other banks as a result of an assessment of increase in risk-weighted assets and in order to increase total asset, low-capital banks increase heavily risk-weighted assets significantly less than other banks (Beatty and Gron, 2001).

\subsection{Basel II}

In order to increase the capital adequacy ratio imposed by the capital regulation, banks can increase equity capital or reduce risk-weighted asset by adjusting asset portfolio. Hyun and Rhee (2011) shows that to meet the higher capital ratio the existing shareholders of a bank will prefer to reduce high-risk assets to meet the higher capital ratio and don't desire to issue new equity to the public even if there is no cost associated with the equity issue. Additionally, Basel II requires banks to estimate the default probability more conservatively during depression and they require more capital which may lead to credit crunch (Hyun and Rhee, 2011).

Again, banks adjust their loan portfolio because of the implementation of Basel II. Jacques (2008) analyses the adjustment of bank's low and high credit risk commercial loans under Basel II. Capital regulation forces capital-constrained banks generally reduce total lending but particularly reduce high-risk loans in response to an undesirable capital shock (Jacques, 2008). As a result of an undesirable capital shock, capital-constrained banks reduce high credit risk loans and may enhance low credit risk loans and the extent of reduction in high-risk loans is more under Basel II compared to Basel I (Jacques, 2008). 
In order to maintain the capital ratio banks adjust the asset portfolio. Banks try to maintain a certain capital ratio and adjusting the regulatory capital ratio by issuing new equity is more effective than by changing the asset portfolio or changing the riskiness of assets (Memmel and Raupach, 2010). Again, commercial banks have radically shifted their portfolios to real-estate loans considered as safe assets and mainly the capital-constrained banks have restructured their portfolios (Blasko and Sinkey, 2006). But by shifting portfolios into safe assets, such as mortgages, although banks are required to maintain lower capital but face more interest-rate risk (Blasko and Sinkey, 2006).

Capital regulation affects the loan pricing of banks. Repullo and Suarez (2004) analyse the loan pricing implications of Basel II. Low risk firms choose banks adopting the IRB approach to borrow at low rate, while high-risk firms choose banks that adopt the less risk-sensitive standardized approach to avoid high borrowing rate (Repullo and Suarez, 2004). But bank capital is expected to be less variable under the Basel II compared to Basel I (Zicchino, 2006). Under Basel II, the loan risk-weights in the capital ratio are affected by macroeconomic shock because a negative macroeconomic shock causes capital constraint tighter and a positive shock causes it looser (Zicchino, 2006).

Banks may maintain capital buffer to capture the variations in minimum capital. During the worse economic condition the credit quality is expected to decline and banks will require more capital (Heid, 2007). The excess capital is expected to alleviate the impact of changes in capital charges in relation to the cyclicality of lending (Heid, 2007). Under Basel I framework the cutback in lending causes a raise in the capital buffer during an economic recession but under Basel II the capital buffer will actually decrease during an economic recession, because the reduction in lending will generally be overcompensated by the increase in the average risk weights (Heid, 2007). Davis (2005) states Basel II could affect the fund supply and lending rate of banks. If the true risks are not reflected accurately by the regulatory risk weight schedules under the standardised approach, loan pricing and credit availability can be distorted (Davis, 2005).

\subsection{Basel III}

Systemic risk is the risk of distress in the financial system caused by an imbalance or a failure of a significant part of the financial sector that can potentially cause severe negative consequences for the real economy. It is found in the work of Stefan (2011) that systemic risk appears endogenously and comes with negative externalities, which cause financial instability. Basel III needs further regulatory adjustments such as a risk-weighted leverage ratio; a more detailed treatment for procyclicality; adjustments for the NSFR (Net Stable Funding ratio); and internalization of negative externalities from financial institutions (Stefan, 2011). According to the study of Simone (2011), the new capital requirement for incremental credit risks under Basel III might be significantly higher than the existing capital regulations and Basel III will cause a much greater increase in capital. However, banks may be able to report lower sensitivity to Basel III because the risk reductions can be achieved through hedging (Simone, 2011). Davis (2011) raises the issue that whether the liquidity adequacy in both systemic stress and individual bank stress can be managed by one policy instrument named liquidity coverage ratio of Basel III. Furthermore, it is very much critical to determine the appropriate fee for the fee based liquidity facility at the Reserve Bank of Australia to maintain the shortage of high quality liquid assets proposed by Basel III (Davis, 2011).

\subsection{Summary of Literature}

The existing literature shows that the stricter capital regulation causes banks to shrink assets which is named as capital crunch hypothesis (Brinkmann and Horvitz, 1995a, Peek and Rosengren, 1995a). In addition, the current literature finds the evidence of credit crunch hypothesis, which predicts that more rigorous capital regulation induces banks to reduce loan supply (Hyun and Rhee, 2011, Berger and Udell, 1994). Again, the capitalconstrained banks reallocate their asset portfolios from high-risk assets to low-risk assets because of the implementation of the stricter capital regulation (Montgomery, 2005, Jacques, 2008, Hall, 1993). As a result of capital regulation banks adjust their asset portfolios more often than liabilities (Memmel and Raupach, 2010). Basel II increases procyclicality and a negative macroeconomic shock makes capital constraint tighter whereas a positive shock makes it looser (Zicchino, 2006); (Heid, 2007, Jacques, 2008). No prior study addresses the issue of the shrinkage of assets and loans and the reallocation of asset portfolio in the Australian context because of the changes in capital regulation come with Basel II. This research fills that gap.

\subsection{Summary of Hypotheses}

Based on the above discussion, we develop four hypotheses related to the first research question of this paper (RQ1: Have the growth of various risky assets been affected by the changes of capital regulation come with Basel II?)

$\mathrm{H}_{1}$ :The changes in the capital regulations made by Basel II cause a decrease in the growth of heavily risk-weighted assets 
$\mathrm{H}_{2}$ :The changes in the capital regulations made by Basel II cause an increase in the growth of low risk-weighted assets

$\mathrm{H}_{3}$ :The changes in the capital regulations made by Basel II cause a decrease in the growth of total assets

$\mathrm{H}_{4}$ : The changes in the capital regulations made by Basel II cause an increase in the growth of equity and subordinated debt

Related to the second research question (RQ 2: Is the growth of various risky assets different in the pre- and postBasel II period?), we develop four hypotheses as follows:

$\mathrm{H}_{5}$ :The growth of heavily risk-weighted assets is lower in the post-Basel II period compared to the pre-Basel-II period

$\mathrm{H}_{6}$ :The growth of low risk-weighted assets is higher in the post-Basel II period compared to the pre-Basel-II period $\mathrm{H}_{7}$ :The growth of total assets is lower in the post-Basel II period compared to the pre-Basel-II period

$\mathrm{H}_{8}$ :The growth of equity and subordinated debt is higher in the post-Basel II period compared to the pre-Basel-II period

\section{Data and Methodology}

This section discusses about the data and methodology of this paper. This paper uses panel data from all 14 local and 8 foreign banks operating in Australia for the fiscal years 2000-2010 in order to examine the impact of capital adequacy regulation on bank portfolios. Basel III capital requirement was finalised on June 2011. As we stated, the objective of this paper is to investigate the effect of Basel II capital requirement in Australia, so we limit our dataset for the empirical study until 2010. Data are collected from the banks' balance sheets and income statements. This paper analyses local and foreign banks separately because of their mode of operation and differences in services they offer.

Balance sheet data of total assets, total loans, mortgages, investment in equity securities, investment in government securities, equity, subordinated debt, and capital ratios of individual banks are collected from Bankscope database compiled by Bureau van Dijk. Annual data of individual Australian banks have been used in this paper. For all the banks, please note that the company data are used and not the consolidated one. Data that are missing in Bankscope have been collected from the annual reports of individual banks. Balance sheet data also have been collected from Fin Analysis, Mint Global and Connect4.

The variable weighted-average rate on credit outstanding for large businesses is considered as Lending Rates. Lending Rates are collected from Reserve Bank of Australia's (RBA) Indicator Lending Rates statistics and oneyear term deposit rate is considered as the borrowing rate. In addition, deposit rates are collected from RBA's retail deposit rate and investment rates statistics. Original annual expenditure on gross domestic product (GDP) at current prices has been collected from Australian Bureau of Statistics. Lending rates, borrowing rates and GDP are matched to year ending of banks.

\subsection{Operationalization of Variables}

In this paper, loan and equity investment are considered as high-risk assets. Subordinated debt and mortgages are considered as low-risk assets. As mortgages are a part of total loans, they are separated from total loans and hence the residual of total loans is called as Net Loan, which is actually non-residential loan. This will help to analyse the impact of capital regulations on non-residential loans. The growth rate of GDP and spread between lending rate and deposit rate of banks have been considered as a factor to influence the growth of banks' assets.

The variables and their operationalization are summarized below:

$$
\begin{aligned}
& \mathrm{TCR}=\text { Total Capital Ratio }=\frac{\text { Tier } 1 \text { Capital+Tier } 2 \text { Capital }}{\text { Risk-Weighted Asset and Off-balance sheet risks }} \\
& \mathrm{T} 1 \mathrm{CR}=\text { Tier } 1 \text { Capital Ratio }=\frac{\text { Tier } 1 \text { Capital }}{\text { Risk-Weighted Asset and Off-balance sheet risks }}
\end{aligned}
$$

Tier 1 capital $=$ Equity + Noncumulative preferred stock net of goodwill

Tier 2 capital $=$ Cumulative perpetual preferred stock + Certain types of 99-year debenture issues + Loan loss reserves + Subordinated debt (i.e., debt subordinated to depositors) with an original maturity of more than five years.

Total capital ratio and tier 1 capital ratio are calculated according to Basel rules.

\subsection{The Model}

The model and variables of this paper are an extension of the previous study by Montgomery (2005). This analysis tries to identify the empirical relationship between the growth of various classes of bank's assets with the bank's risk-adjusted capital ratio, both before and after the implementation of Basel II in Australia on January 2008. This paper also analyses whether the banks issue equity and/or subordinated debt to maintain the growth of total riskweighted assets because growth of total risk-weighted assets requires more capital to maintain the capital ratio. In this paper, two types of capital ratios, total capital ratio and tier 1 capital ratio, are considered. Montgomery (2005) uses book-based capital-to-asset ratio but this paper uses risk-adjusted capital ratio, calculated according to the 
Basel rules. The growth of banks' assets is influenced by macroeconomic events. The lagged differential between loan and deposit rates and lagged GDP growth are considered to control for macroeconomic events. Here, it is considered that the growth of an asset depends on its last year's growth rate, lagged differential between loan and deposit rate, lagged GDP growth rate and capital ratio. The control variables of the model are growth rate of GDP, lending rate and deposit rate of banks.

The model is expressed in equation 1 below:

$$
\begin{aligned}
\Delta \log \left(A_{\mathrm{i}, \mathrm{t}+1}\right)=\beta_{1}+ & \beta_{2} \Delta \log \left(A_{\mathrm{i}, \mathrm{t}}\right)+\beta_{3}\left(r_{t}^{L}-r_{t}^{D}\right)+\beta_{4} \Delta \log \left(\mathrm{GDP}_{\mathrm{t}}\right)+\beta_{5} \log \left(\mathrm{TCR}_{\mathrm{i}, \mathrm{t}}\right) \\
& +\varepsilon_{\mathrm{i}, \mathrm{t}+1}
\end{aligned}
$$

where, $\mathrm{i}=$ Individual bank; $\mathrm{t}=$ Time period; $\mathrm{A}=$ Bank's various types of assets such as Total asset, Total Loan, Net Loan, Equity Investment, Mortgage and Government Securities and Bank's various types of liabilities such as Total Equity and Subordinated Debt; $\mathrm{r}^{\mathrm{L}}=$ Interest rate on loan; $\mathrm{r}^{\mathrm{D}}=$ Interest rate on deposit; $\mathrm{GDP}=\mathrm{Gross}$ domestic product; TCR=Total Capital Ratio.

The growth rates of various classes of the bank's assets and liabilities are regressed upon lagged asset growth, the differential between the interest rates on loans and deposits, lagged growth in GDP, and the bank's capital ratio. Equation (1) is applied to identify the growth rate of total assets, loans, equity investments, mortgages, net loans, investment in government securities, equity, and subordinated debt of Australian banks.

Equation 2, shown below, is developed to identify the effect of Basel II on the growth rate of assets.

$$
\begin{aligned}
\Delta \log \left(\mathrm{A}_{\mathrm{i}, \mathrm{t}+1}\right)= & \delta_{1}+\delta_{2} \Delta \log \left(\mathrm{A}_{\mathrm{i}, \mathrm{t}}\right)+\delta_{3}\left(r_{t}^{L}-r_{t}^{D}\right)+\delta_{4} \Delta \log \left(\mathrm{GDP} P_{\mathrm{t}}\right)+\delta_{5} \log \left(\mathrm{TCR}_{\mathrm{i}, \mathrm{t}}\right) \\
& +\delta_{6} \log \left(\mathrm{TCR}_{\mathrm{i}, \mathrm{t}}\right) * \text { Basel II }+\delta_{7} \text { Basel II }+u_{\mathrm{i}, \mathrm{t}+1}
\end{aligned}
$$

Equation 2 is derived from equation 1 to identify the effect of Basel II. In equation 2, a dummy variable, Basel II, is taken to identify the changes in the sensitivity of capital ratio on assets due to Basel II. The dummy variable, Basel II, has a value of 1 in post-Basel II period i.e., after January, 2008 and value of 0 in the pre-Basel II period i.e., before January, 2008. The slope dummy variable, TCR*Basel II, captures the effect of total capital ratio on the growth rate of asset and liability in the post-Basel II period as a result of changes in the capital regulations by Basel II. The intercept dummy variable, Basel II, identifies the changes in the growth rate between the pre- and post-Basel II period.

To identify the impact of Tier 1 Capital Ratio equations 3 and 4 are used:

$$
\begin{aligned}
& \Delta \log \left(A_{\mathrm{i}, \mathrm{t}+1}\right)=\beta_{1}+\beta_{2} \Delta \log \left(A_{\mathrm{i}, \mathrm{t}}\right)+\beta_{3}\left(r_{t}^{L}-r_{t}^{D}\right)+\beta_{4} \Delta \log \left(\mathrm{GDP}_{\mathrm{t}}\right)+\beta_{5} \log \left(\mathrm{T}_{1 \mathrm{CR}} \mathrm{i}, \mathrm{t}\right) \\
& +\varepsilon_{\mathrm{i}, \mathrm{t}+1} \\
& \Delta \log \left(\mathrm{A}_{\mathrm{i}, \mathrm{t}+1}\right)=\delta_{1}+\delta_{2} \Delta \log \left(\mathrm{A}_{\mathrm{i}, \mathrm{t}}\right)+\delta_{3}\left(r_{t}^{L}-r_{t}^{D}\right)+\delta_{4} \Delta \log \left(\mathrm{GD} P_{\mathrm{t}}\right)+\delta_{5} \log \left(\mathrm{T} 1 \mathrm{CR} \mathrm{R}_{\mathrm{i}, \mathrm{t}}\right) \\
& +\delta_{6} \log \left(\mathrm{T} 1 \mathrm{CR}_{\mathrm{i}, \mathrm{t}}\right) * \text { Basel II }+\delta_{7} \text { Basel II }+u_{\mathrm{i}, \mathrm{t}+1}
\end{aligned}
$$

where, $\mathrm{T} 1 \mathrm{CR}=$ Tier 1 Capital Ratio

\subsection{Data Analysis}

This paper performs panel unit root tests to check whether the series are stationary. According to panel unit root tests, the first difference of log of total asset, total loan, net loan, mortgages, equity investment, investment in government securities, total equity and subordinated debt do not have unit root, which indicates that all these series are stationary at the 5\% level of significance. Lending rate and deposit rate are also stationary. Nevertheless, the first difference of log of GDP has one unit root and hence non-stationary. The growth rate of GDP is required in this model, which is the first difference of GDP. Therefore, this paper ignores the non-stationarity of the first difference of GDP. The results of unit root test are similar for both domestic and international banks.

Again, the "Jarque-Bera" test is performed to check the normality of the residuals of the panel regressions. The residuals of the panel regressions for assets and liabilities of local bank are normally distributed at 5\% level of significance. However, the residuals of the panel regressions for assets and liabilities except total equity of foreign banks are not normally distributed at 5\% level of significance. One potential reason may be the limited data availability of foreign banks operating in Australia. These banks do not publish annual reports and therefore, the data missing in Bankscope cannot be collected.

\subsection{Expected Relationship of Variables}

Table 1 shows the summary of relationships between the variables of this paper. The relationship between growth rate of loans and equity investments with TCR and T1CR should be positive in the post-Basel II period. Such relationship is expected as banks with high risk-adjusted capital ratio would invest more in high-risk assets to maintain their statutory capital. Whereas, the relationship between growth rate of mortgages and government securities with TCR and T1CR should be negative in the post-Basel II period. It indicates that banks with low riskadjusted capital ratio will increase investment in safe securities such as mortgages and government securities. The relationship between the growth rate of total asset with TCR and T1CR should be positive as the banks with high 
risk-adjusted capital ratio would logically invest more. Finally, the relationship between growth rate of equity and subordinated debt with TCR and T1CR should be negative in the post-Basel II period because banks with low riskadjusted capital ratio would issue more equity or subordinated debt in order to maintain TCR and T1CR.

The coefficient of intercept dummy variable, Basel II, should be negative for loan, equity investment and total asset because these assets should face lower growth rate in the post-Basel II period. Whereas, the intercept dummy variable should be positive for mortgages, government securities, equity, and subordinated debt because these assets and liabilities should face higher growth rate in the post-Basel II period.

Table 1: Expected Relationship of Variables

\begin{tabular}{clc}
\hline Hypothesis Number & \multicolumn{1}{c}{ Variable } & Expectation \\
\hline 1 & Loan, Equity Investment & $\delta_{6}>0$ \\
2 & Mortgages, Government Securities & $\delta_{6}<0$ \\
3 & Total Asset & $\delta_{6}>0$ \\
4 & Equity, Subordinated Debt & $\delta_{6}<0$ \\
5 & Loan, Equity Investment & $\delta_{7}<0$ \\
6 & Mortgages, Government Securities & $\delta_{7}>0$ \\
7 & Total Asset & $\delta_{7}<0$ \\
8 & Equity, Subordinated Debt & $\delta_{7}>0$ \\
\hline
\end{tabular}

\section{Findings and Discussion}

The empirical results are divided into two sub-sections 5.1 and 5.2. The sensitivity of various assets and liabilities to regulatory total capital ratio and to tier 1 capital ratio are presented in sub-sections 5.1 and 5.2 respectively.

\subsection{Sensitivity to Total Capital Ratio}

The sensitivity of high-risk weighted and low-risk weighted assets, total assets and liability to regulatory total capital are exhibited in the following paragraphs.

\subsubsection{High Risk-Weighted Asset}

Table 2 shows the sensitivity of high risk-weighted assets such as total loan, net loan and equity investment to regulatory total capital ratio in the pre-Basel II and post-Basel II period. The coefficient and t-Statistic of the variables are shown in the tables. The t-Statistic of the variables is shown in the bracket. The post-Basel II dummy variable, Basel II, is statistically significant and positive for domestic banks' holdings of net loans and equity investments. This means that growth of these high-risk assets is significantly higher in the post-Basel II period. In the pre-Basel II period, total capital ratio becomes statistically significantly positive for total loans of international banks and equity investments of domestic banks. This can be interpreted as that the slower growth of high-risk assets in the pre-Basel II period are caused by Basel I. In the post-Basel II period, total capital ratio becomes statistically significantly negative for net loans and equity investments of domestic banks. This means that the higher growth of net loans and equity investments of domestic banks in the post-Basel II period is influenced by the regulatory changes of Basel II.

\section{Table: 2 Sensitivity of high-risk assets to total capital ratio}

This table reports the estimation results from the following regression models (see equation 2):

$\Delta \log \left(\mathrm{A}_{\mathrm{i}, \mathrm{t}+1}\right)=\delta_{1}+\delta_{2} \Delta \log \left(\mathrm{A}_{\mathrm{i}, \mathrm{t}}\right)+\delta_{3}\left(r_{t}^{L}-r_{t}^{D}\right)+\delta_{4} \Delta \log \left(\mathrm{GDP} P_{\mathrm{t}}\right)+\delta_{5} \log \left(\mathrm{TCR}_{\mathrm{i}, \mathrm{t}}\right)+\delta_{6} \log \left(\mathrm{TCR}_{\mathrm{i}, \mathrm{t}}\right) *$ Basel II + $\delta_{7}$ Basel II $+u_{\mathrm{i}, \mathrm{t}+1}$

where, $A_{t}$ refer to Total Loan, Net Loan and Equity Investment. $\mathrm{r}^{\mathrm{L}}$ refer to Interest rate on loan, $\mathrm{r}^{\mathrm{D}}$ refer to Interest rate on deposit, GDP refer to Gross domestic product, TCR refer to Total Capital Ratio. Balance Sheet data of individual Banks have been collected mainly from Bankscope database compiled by Bureau van Dijk. Lending Rates are collected from Reserve Bank of Australia's (RBA) Indicator Lending Rates statistics and one-year term deposit rate is considered as the borrowing rate which is collected from RBA's retail deposit rate and investment rates statistics. Basel II is a dummy variable which has a value of 1 in post-Basel II period i.e., after January, 2008 and value of 0 in the pre-Basel II period i.e., before January, 2008.*,**, and *** denote 10\%, 5\%, and 1\% significance levels, respectively. The sample covers the annual data from 2000to 2010. 


\begin{tabular}{|c|c|c|c|c|c|}
\hline Asset & \multicolumn{2}{|l|}{ Total Loan } & Net Loan & \multicolumn{2}{|c|}{ Equity Investment } \\
\hline Sample & Domestic & Intl. & Domestic & Domestic & Intl. \\
\hline No. of Obs. & 111 & 29 & 78 & 94 & 8 \\
\hline Constant & $\begin{array}{l}-0.3489 \\
(-0.6849)\end{array}$ & $\begin{array}{l}-0.5359 \\
(-1.5393)\end{array}$ & $\begin{array}{l}-0.0746 \\
(-0.1039)\end{array}$ & $\begin{array}{l}-2.0033 \\
(-1.4040)\end{array}$ & $\begin{array}{l}7.7331 \\
(1.6723)\end{array}$ \\
\hline Basel II & $\begin{array}{l}0.8661 \\
(0.8762)\end{array}$ & $\begin{array}{l}-0.0013 \\
(-0.0034)\end{array}$ & $\begin{array}{l}3.2346^{* *} \\
(2.4750)\end{array}$ & $\begin{array}{l}6.5750 * * * \\
(2.5213)\end{array}$ & $\begin{array}{l}3.8939 \\
(2.2826)\end{array}$ \\
\hline$\Delta \log \left(A_{i, t}\right)$ & $\begin{array}{l}-0.1053 \\
(-0.8417)\end{array}$ & $\begin{array}{l}-0.0846 \\
(-0.5053)\end{array}$ & $\begin{array}{l}-0.0023 \\
(-0.0186)\end{array}$ & $\begin{array}{l}-0.1704 \\
(-1.5753)\end{array}$ & $\begin{array}{l}0.2362 \\
(1.1341)\end{array}$ \\
\hline$r_{t}^{L}-r_{t}^{D}$ & $\begin{array}{l}-0.0954 \\
(-1.6311)\end{array}$ & $\begin{array}{l}-0.0243 \\
(-0.5772)\end{array}$ & $\begin{array}{l}-0.0466 \\
(-0.9736)\end{array}$ & $\begin{array}{l}-0.0027 \\
(-0.0141)\end{array}$ & $\begin{array}{l}0.2041 \\
(0.8432)\end{array}$ \\
\hline$\Delta \log \left(\mathrm{G} D P_{\mathrm{t}}\right)$ & $\begin{array}{l}1.0740 \\
(0.3553)\end{array}$ & $\begin{array}{l}1.3408 \\
(1.0529)\end{array}$ & $\begin{array}{l}-0.5773 \\
(-0.2753)\end{array}$ & $\begin{array}{l}-6.1046 \\
(-0.7132)\end{array}$ & $\begin{array}{l}-122.0031 \\
(-2.3874)\end{array}$ \\
\hline $\log \left(\mathrm{TCR}_{\mathrm{i}, \mathrm{t}}\right)$ & $\begin{array}{l}0.2637 \\
(1.4896)\end{array}$ & $\begin{array}{l}0.2283 * * \\
(2.2728)\end{array}$ & $\begin{array}{l}0.1369 \\
(0.4708)\end{array}$ & $\begin{array}{l}1.1061 * * \\
(2.3011)\end{array}$ & $\begin{array}{l}0.5234 \\
(0.9383)\end{array}$ \\
\hline $\log \left(\mathrm{TCR}_{\mathrm{i}, \mathrm{t}}\right) *$ Basel II & $\begin{array}{l}-0.3919 \\
(-0.9719)\end{array}$ & $\begin{array}{l}-0.0090 \\
(-0.0745)\end{array}$ & $\begin{array}{l}-1.3657 * * * \\
(-2.5155)\end{array}$ & $\begin{array}{l}-2.7487 * * * \\
(-2.5994)\end{array}$ & $\begin{array}{l}-1.3529 \\
(-2.2301)\end{array}$ \\
\hline
\end{tabular}

\subsubsection{Low Risk-Weighted Asset}

The sensitivity of low risk-weighted assets to regulatory total capital ratio in the pre-Basel II and post-Basel II period for domestic banks are shown in Table 3. International banks do not hold government securities and mortgages. The post-Basel II dummy variable, Basel II, is not statistically significant for domestic banks' holdings of government securities and mortgages. This suggests that there is no change in the growth of these low-risk assets in the post-Basel II period. Both in the pre-Basel II and post-Basel II period, the total capital ratio becomes statistically insignificant for government securities and mortgages of domestic banks. This means that the growth of low-risk assets is not influenced by the regulatory changes of Basel I and II.

Table: 3 Sensitivity of low-risk assets to total capital ratio

This table reports the estimation results from the following regression models (see equation 2):

$\Delta \log \left(\mathrm{A}_{\mathrm{i}, \mathrm{t}+1}\right)=\delta_{1}+\delta_{2} \Delta \log \left(\mathrm{A}_{\mathrm{i}, \mathrm{t}}\right)+\delta_{3}\left(r_{t}^{L}-r_{t}^{D}\right)+\delta_{4} \Delta \log \left(\mathrm{GDP}_{\mathrm{t}}\right)+\delta_{5} \log \left(\mathrm{TCR}_{\mathrm{i}, \mathrm{t}}\right)+\delta_{6} \log \left(\mathrm{TCR}_{\mathrm{i}, \mathrm{t}}\right) *$ Basel II + $\delta_{7}$ Basel II $+u_{\mathrm{i}, \mathrm{t}+1}$

where, $A_{t}$ refer to Government Securities and Mortgages. $\mathrm{r}^{\mathrm{L}}$ refer to Interest rate on loan, $\mathrm{r}^{\mathrm{D}}$ refer to Interest rate on deposit, GDP refer to Gross domestic product, TCR refer to Total Capital Ratio. Balance Sheet data of individual Banks have been collected mainly from Bankscope database compiled by Bureau van Dijk. Lending Rates are collected from Reserve Bank of Australia's (RBA) Indicator Lending Rates statistics and one-year term deposit rate is considered as the borrowing rate which is collected from RBA's retail deposit rate and investment rates statistics. Basel II is a dummy variable which has a value of 1 in post-Basel II period i.e., after January, 2008 and value of 0 in the pre-Basel II period i.e., before January, 2008. *, **, and *** denote $10 \%, 5 \%$, and $1 \%$ significance levels, respectively. The sample covers the annual data from 2000to 2010.

\begin{tabular}{lll}
\hline Asset & Government Securities & Mortgages \\
$\Delta \log \left(A_{i, t+1}\right)$ & & \\
Sample & Domestic & Domestic \\
No. of Obs. & 70 & 78 \\
\hline Constant & 0.8438 & -0.4724 \\
& $(0.6629)$ & $(-0.8887)$ \\
Basel II & -2.6603 & 1.4362 \\
& $(-1.1637)$ & $(1.5433)$ \\
$\Delta \log \left(A_{i, t}\right)$ & -0.0771 & -0.0879 \\
& $(-0.6406)$ & $(-0.7271)$ \\
$r_{t}^{L}-r_{t}^{D}$ & 0.2509 & -0.0453 \\
$\Delta \log \left(\mathrm{GDP}_{\mathrm{t}}\right)$ & $(1.2825)$ & $(-1.2751)$ \\
$\log \left(\mathrm{TCR}_{\mathrm{i}, t}\right)$ & -8.5009 & -0.8896 \\
& $(-1.1010)$ & $(-0.5752)$ \\
$\log \left(\mathrm{TCR}_{\mathrm{i}, t}\right) *$ Basel II & -0.3616 & 0.3380 \\
& $(-0.8312)$ & 1.5708 \\
\hline $\mathbf{5 . 3 T} 0 t$ Asst & 1.3769 & -0.6188 \\
\end{tabular}

5.1.3 Total Asset

Table 4 shows the sensitivity of total assets to regulatory total capital ratio in the pre-Basel II and post-Basel II 
period for both domestic and international banks. The post-Basel II dummy variable, Basel II, is not statistically significant for domestic and international banks' holdings of total assets, suggesting no change in the growth of total assets in the post-Basel II period. In the pre-Basel II period, total capital ratio becomes statistically significantly positive for total assets of domestic banks. This can be interpreted as that the slower growth of total assets of domestic banks are caused by the regulatory changes of Basel I. In the post-Basel II period, total capital ratio becomes statistically insignificant for total assets of domestic and international banks. This means that the growth of total assets is not influenced by the regulatory changes of Basel II.

\section{Table: 4 Sensitivity of total assets to total capital ratio}

This table reports the estimation results from the following regression models (see equation 2):

$\Delta \log \left(\mathrm{A}_{\mathrm{i}, \mathrm{t}+1}\right)=\delta_{1}+\delta_{2} \Delta \log \left(\mathrm{A}_{\mathrm{i}, \mathrm{t}}\right)+\delta_{3}\left(r_{t}^{L}-r_{t}^{D}\right)+\delta_{4} \Delta \log \left(\mathrm{GDP} P_{\mathrm{t}}\right)+\delta_{5} \log \left(\mathrm{TCR}_{\mathrm{i}, \mathrm{t}}\right)+\delta_{6} \log \left(\mathrm{TCR}_{\mathrm{i}, \mathrm{t}}\right) *$ Basel II + $\delta_{7}$ Basel II $+u_{\mathrm{i}, \mathrm{t}+1}$

where, $A_{t}$ refer to Total Asset. $r^{\mathrm{L}}$ refer to Interest rate on loan, $\mathrm{r}^{\mathrm{D}}$ refer to Interest rate on deposit, GDP refer to Gross domestic product, TCR refer to Total Capital Ratio. Balance Sheet data of individual Banks have been collected mainly from Bankscope database compiled by Bureau van Dijk. Lending Rates are collected from Reserve Bank of Australia's (RBA) Indicator Lending Rates statistics and one-year term deposit rate is considered as the borrowing rate which is collected from RBA's retail deposit rate and investment rates statistics. Basel II is a dummy variable which has a value of 1 in post-Basel II period i.e., after January, 2008 and value of 0 in the preBasel II period i.e., before January, 2008. * **, and *** denote $10 \%, 5 \%$, and $1 \%$ significance levels, respectively. The sample covers the annual data from 2000to 2010.

\begin{tabular}{|c|c|c|}
\hline Asset & \multicolumn{2}{|l|}{ Total Assets } \\
\hline \multicolumn{3}{|l|}{$\begin{array}{l}\text { Asset } \\
\Delta \log \left(A_{i, t+1}\right)\end{array}$} \\
\hline Sample & Domestic & Intl. \\
\hline No. of Obs. & 112 & 29 \\
\hline Constant & $\begin{array}{l}-0.3638 \\
(-1.0631)\end{array}$ & $\begin{array}{l}0.0785 \\
(0.2142)\end{array}$ \\
\hline Basel II & $\begin{array}{l}0.8493 \\
(1.3188)\end{array}$ & $\begin{array}{l}-0.2849 \\
(-0.6776)\end{array}$ \\
\hline$\Delta \log \left(A_{i, t}\right)$ & $\begin{array}{c}0.2385^{* *} \\
(2.2690)\end{array}$ & $\begin{array}{l}-0.0397 \\
(-0.2322)\end{array}$ \\
\hline$r_{t}^{L}-r_{t}^{D}$ & $\begin{array}{l}-0.0870 * * \\
(-2.2200)\end{array}$ & $\begin{array}{l}-0.0142 \\
(-0.2836)\end{array}$ \\
\hline$\Delta \log \left(\mathrm{G} D P_{\mathrm{t}}\right)$ & $\begin{array}{l}1.3185 \\
(0.6546)\end{array}$ & $\begin{array}{l}1.0498 \\
(0.7851)\end{array}$ \\
\hline $\log \left(\mathrm{TCR}_{\mathrm{i}, \mathrm{t}}\right)$ & $\begin{array}{l}0.2403 * * \\
(2.0122)\end{array}$ & $\begin{array}{l}0.0312 \\
(0.3048)\end{array}$ \\
\hline $\log \left(\mathrm{TCR}_{\mathrm{i}, \mathrm{t}}\right) *$ Basel II & $\begin{array}{l}-0.3935 \\
(-1.5017)\end{array}$ & $\begin{array}{l}0.0552 \\
(0.4023)\end{array}$ \\
\hline
\end{tabular}

\subsubsection{Liability}

The sensitivity of equity and subordinated debt to regulatory total capital ratio in the pre-Basel II and post-Basel II period for both domestic and international banks are shown in table 5. The post-Basel II dummy variable, Basel II, is not statistically significant for domestic and international banks' holdings of equity and subordinated debt, which means that thereis no change in the growth of equity and subordinated debt in the post-Basel II period. In the pre-Basel II period, total capital ratio becomes statistically significant and positive for equity and subordinated debt of domestic banks. This suggests that the slower growth of equity and subordinated debt of domestic banks in the post-Basel II period are caused by the regulatory changes of Basel I. However, in the post-Basel II period, total capital ratio becomes statistically insignificant for the domestic and foreign banks' holdings of equity and subordinated debt. This means that the growth of equity and subordinated debt is not influenced by the regulatory changes of Basel II.

\section{Table: 5 Sensitivity of liabilities to total capital ratio}

This table reports the estimation results from the following regression models (see equation 2):

$\Delta \log \left(\mathrm{A}_{\mathrm{i}, \mathrm{t}+1}\right)=\delta_{1}+\delta_{2} \Delta \log \left(\mathrm{A}_{\mathrm{i}, \mathrm{t}}\right)+\delta_{3}\left(r_{t}^{L}-r_{t}^{D}\right)+\delta_{4} \Delta \log \left(\mathrm{GDP} P_{\mathrm{t}}\right)+\delta_{5} \log \left(\mathrm{TCR}_{\mathrm{i}, \mathrm{t}}\right)+\delta_{6} \log \left(\mathrm{TCR}_{\mathrm{i}, \mathrm{t}}\right) *$ Basel II + $\delta_{7}$ Basel II $+u_{i, t+1}$

where, $A_{t}$ refer to Equity and Subordinated Debt. $\mathrm{r}^{\mathrm{L}}$ refer to Interest rate on loan, $\mathrm{r}^{\mathrm{D}}$ refer to Interest rate on deposit, GDP refer to Gross domestic product, TCR refer to Total Capital Ratio. Balance Sheet data of individual Banks have been collected mainly from Bankscope database compiled by Bureau van Dijk. Lending Rates are collected from Reserve Bank of Australia's (RBA) Indicator Lending Rates statistics and one-year term deposit rate is considered as the borrowing rate which is collected from RBA's retail deposit rate and investment rates statistics. 
Basel II is a dummy variable which has a value of 1 in post-Basel II period i.e., after January, 2008 and value of 0 in the pre-Basel II period i.e., before January, 2008. * **, and *** denote $10 \%, 5 \%$, and $1 \%$ significance levels, respectively. The sample covers the annual data from 2000to 2010.

\begin{tabular}{|c|c|c|c|c|}
\hline $\begin{array}{l}\text { Liability } \\
\Delta \log \left(A_{i, t+1}\right)\end{array}$ & Equity & & Subordinate & \\
\hline Sample & Domestic & Intl. & Domestic & Intl. \\
\hline No. of Obs. & 112 & 29 & 109 & 12 \\
\hline Constant & $\begin{array}{l}-0.5955 \\
(-1.4931)\end{array}$ & $\begin{array}{l}0.2537 \\
(0.9539)\end{array}$ & $\begin{array}{l}-0.2201 \\
(-0.4427)\end{array}$ & $\begin{array}{l}0.8977 \\
(0.2416)\end{array}$ \\
\hline Basel II & $\begin{array}{l}0.6354 \\
(0.8440)\end{array}$ & $\begin{array}{l}-0.0630 \\
(-0.2102)\end{array}$ & $\begin{array}{l}1.2724 \\
(1.4188)\end{array}$ & $\begin{array}{l}1.8521 \\
(0.5766)\end{array}$ \\
\hline$\Delta \log \left(A_{i, t}\right)$ & $\begin{array}{l}-0.0791 \\
(-0.8130)\end{array}$ & $\begin{array}{l}0.1264 \\
(0.5971)\end{array}$ & $\begin{array}{l}-0.2482 * * * \\
(-2.5860)\end{array}$ & $\begin{array}{l}-0.4039 \\
(-0.4553)\end{array}$ \\
\hline$r_{t}^{L}-r_{t}^{D}$ & $\begin{array}{l}0.0052 \\
(0.1124)\end{array}$ & $\begin{array}{l}0.0211 \\
(0.6216)\end{array}$ & $\begin{array}{l}-0.0873 \\
(-1.5720)\end{array}$ & $\begin{array}{l}-0.1458 \\
(-0.5411)\end{array}$ \\
\hline$\Delta \log \left(G D P_{\mathrm{t}}\right)$ & $\begin{array}{l}2.4389 \\
(1.0341)\end{array}$ & $\begin{array}{l}-0.6195 \\
(-0.6813)\end{array}$ & $\begin{array}{l}-4.8792 * \\
(-1.7294)\end{array}$ & $\begin{array}{l}-6.1646 \\
(-0.1852)\end{array}$ \\
\hline $\log \left(\mathrm{TCR}_{\mathrm{i}, \mathrm{t}}\right)$ & $\begin{array}{l}0.2365^{*} \\
(1.7018)\end{array}$ & $\begin{array}{l}-0.0501 \\
(-0.6899)\end{array}$ & $\begin{array}{l}0.3841 * * \\
(2.1651)\end{array}$ & $\begin{array}{l}-0.0657 \\
(-0.0708)\end{array}$ \\
\hline $\log \left(\mathrm{TCR}_{\mathrm{i}, \mathrm{t}}\right) *$ Basel II & $\begin{array}{l}-0.2489 \\
(-0.8127)\end{array}$ & $\begin{array}{l}0.0086 \\
(0.0889)\end{array}$ & $\begin{array}{l}-0.5780 \\
(-1.5787)\end{array}$ & $\begin{array}{l}-0.6636 \\
(-0.5323)\end{array}$ \\
\hline
\end{tabular}

\subsection{Sensitivity to Tier 1 Capital Ratio}

The sensitivity of high-risk weighted and low risk weighted assets, total asset and liability to tier 1 capital ratio are displayed in the following paragraphs.

\subsubsection{High Risk-Weighted Asset}

Table 6 shows the sensitivity of high risk-weighted assets such as total loans, net loans and equity investments to the regulatory tier 1 capital ratio during the pre-Basel II and post-Basel II period. The post-Basel II dummy variable, Basel II, is statistically significant and positive for domestic banks' holdings of net loans which means that growth of net loans of domestic banks are significantly higher in the post-Basel II period. In the pre-Basel II period, tier 1 capital ratio becomes statistically significant and positive for total loans of international banks. This suggests that the slower growth of total loans of international banks in the pre-Basel II period are caused by Basel I. In the postBasel II period, tier 1 capital ratio becomes statistically significant and negative for net loan of domestic banks. This means that the higher growth of net loans of domestic banks in the post-Basel II period is influenced by the regulatory changes of Basel II.

Table: 6 Sensitivity of high-risk assets to tier 1 capital ratio

This table reports the estimation results from the following regression models (see equation 4):

$\Delta \log \left(\mathrm{A}_{\mathrm{i}, \mathrm{t}+1}\right)=\delta_{1}+\delta_{2} \Delta \log \left(\mathrm{A}_{\mathrm{i}, \mathrm{t}}\right)+\delta_{3}\left(r_{t}^{L}-r_{t}^{D}\right)+\delta_{4} \Delta \log \left(\mathrm{GD} P_{\mathrm{t}}\right)+\delta_{5} \log \left(\mathrm{T} 1 \mathrm{CR}_{\mathrm{i}, \mathrm{t}}\right)+\delta_{6} \log (\mathrm{T} 1 \mathrm{CR} \mathrm{i}, \mathrm{t}) * \mathrm{Basel} \mathrm{II}+$ $\delta_{7}$ Basel II $+u_{\mathrm{i}, \mathrm{t}+1}$

where, $A_{t}$ refer to Total Loan, Net Loan and Equity Investment. $\mathrm{r}^{\mathrm{L}}$ refer to Interest rate on loan, $\mathrm{r}^{\mathrm{D}}$ refer to Interest rate on deposit, GDP refer to Gross domestic product, T1CR refer to Tier 1 Capital Ratio. Balance Sheet data of individual Banks have been collected mainly from Bankscope database compiled by Bureau van Dijk. Lending Rates are collected from Reserve Bank of Australia's (RBA) Indicator Lending Rates statistics and one-year term deposit rate is considered as the borrowing rate which is collected from RBA's retail deposit rate and investment rates statistics. Basel II is a dummy variable which has a value of 1 in post-Basel II period i.e., after January, 2008 and value of 0 in the pre-Basel II period i.e., before January, 2008.*,**, and *** denote 10\%, 5\%, and 1\% significance levels, respectively. The sample covers the annual data from 2000to 2010. 


\begin{tabular}{|c|c|c|c|c|c|}
\hline Asset & Total Loan & & Net Loan & Equity Inv & ent \\
\hline Sample & Domestic & Intl. & Domestic & Domestic & Intl. \\
\hline No. of Obs. & 110 & 29 & 77 & 94 & 8 \\
\hline Constant & $\begin{array}{l}0.2373 \\
(0.6100)\end{array}$ & $\begin{array}{l}-0.4423 \\
(-1.5572)\end{array}$ & $\begin{array}{l}0.0152 \\
(0.0386)\end{array}$ & $\begin{array}{l}-0.4999 \\
(-0.4422)\end{array}$ & $\begin{array}{l}7.9437 \\
(2.0100)\end{array}$ \\
\hline Basel II & $\begin{array}{l}0.0904 \\
(0.1504)\end{array}$ & $\begin{array}{l}0.0632 \\
(0.2209)\end{array}$ & $\begin{array}{l}1.0128^{*} \\
(1.6505)\end{array}$ & $\begin{array}{l}1.7758 \\
(1.0629)\end{array}$ & $\begin{array}{l}3.2648 \\
(2.7368)\end{array}$ \\
\hline$\Delta \log \left(A_{i, t}\right)$ & $\begin{array}{l}-0.0844 \\
(-0.6549)\end{array}$ & $\begin{array}{l}-0.1195 \\
(-0.7110)\end{array}$ & $\begin{array}{l}0.0024 \\
(0.0185)\end{array}$ & $\begin{array}{l}-0.1334 \\
(-1.1934)\end{array}$ & $\begin{array}{l}0.2147 \\
(1.1051)\end{array}$ \\
\hline$r_{t}^{L}-r_{t}^{D}$ & $\begin{array}{l}-0.0982 * \\
(-1.6571)\end{array}$ & $\begin{array}{l}-0.0300 \\
(-0.7259)\end{array}$ & $\begin{array}{l}-0.0675 \\
(-1.3758)\end{array}$ & $\begin{array}{l}-0.0311 \\
(-0.1536)\end{array}$ & $\begin{array}{l}0.1514 \\
(0.6489)\end{array}$ \\
\hline$\Delta \log \left(G D P_{\mathrm{t}}\right)$ & $\begin{array}{l}0.9683 \\
(0.3133)\end{array}$ & $\begin{array}{l}1.3531 \\
(1.0927)\end{array}$ & $\begin{array}{l}0.3151 \\
(0.1468)\end{array}$ & $\begin{array}{l}-5.7976 \\
(-0.6547)\end{array}$ & $\begin{array}{l}-119.2842 \\
(-2.5917)\end{array}$ \\
\hline $\log \left(\mathrm{T} 1 \mathrm{CR}_{\mathrm{i}, \mathrm{t}}\right)$ & $\begin{array}{l}0.0316 \\
(0.2425)\end{array}$ & $\begin{array}{l}0.2110^{* *} \\
(2.5327\end{array}$ & $\begin{array}{l}0.1072 \\
(0.6663)\end{array}$ & $\begin{array}{l}0.5721 \\
(1.6321)\end{array}$ & $\begin{array}{l}0.4423 \\
(1.3243)\end{array}$ \\
\hline $\log \left(\mathrm{T} 1 \mathrm{CR}_{\mathrm{i}, \mathrm{t}}\right) *$ Basel II & $\begin{array}{l}-0.0853 \\
(-0.3037)\end{array}$ & $\begin{array}{l}-0.0255 \\
(-0.2621)\end{array}$ & $\begin{array}{l}-0.5151 * \\
(-1.7691)\end{array}$ & $\begin{array}{l}-0.9006 \\
(-1.1909)\end{array}$ & $\begin{array}{l}-1.2340 \\
(-2.8905)\end{array}$ \\
\hline
\end{tabular}

\subsubsection{Low Risk-Weighted Asset}

The domestic banks' sensitivity of low risk-weighted assets to regulatory tier 1 capital ratio during the pre-Basel II and post-Basel II period are shown in Table 7. The post-Basel II dummy variable, Basel II, is not statistically significant for domestic banks' holdings of government securities and mortgages, which indicates that there is no change in the growth of these low-risk assets in the post-Basel II period. Both in the pre-Basel II and post-Basel II period, tier 1 capital ratio becomes statistically insignificant for government securities and mortgages of domestic banks. This suggests that the growth of low-risk assets is not influenced by the regulatory changes of Basel I and Basel II.

\section{Table: 7 Sensitivity of low-risk assets to tier 1 capital ratio}

This table reports the estimation results from the following regression models (see equation 4):

$\Delta \log \left(\mathrm{A}_{\mathrm{i}, t+1}\right)=\delta_{1}+\delta_{2} \Delta \log \left(\mathrm{A}_{\mathrm{i}, \mathrm{t}}\right)+\delta_{3}\left(r_{t}^{L}-r_{t}^{D}\right)+\delta_{4} \Delta \log \left(\mathrm{GDP} P_{\mathrm{t}}\right)+\delta_{5} \log \left(\mathrm{T}_{1 C \mathrm{CR}_{\mathrm{i}, \mathrm{t}}}\right)+\delta_{6} \log \left(\mathrm{T}_{1 \mathrm{CR}} \mathrm{i}, \mathrm{t}\right) *$ Basel II + $\delta_{7}$ Basel II $+u_{\mathrm{i}, \mathrm{t}+1}$

where, $A_{t}$ refer to Government Securities and Mortgages. $\mathrm{r}^{\mathrm{L}}$ refer to Interest rate on loan, $\mathrm{r}^{\mathrm{D}}$ refer to Interest rate on deposit, GDP refer to Gross domestic product, T1CR refer to Tier 1 Capital Ratio. Balance Sheet data of individual Banks have been collected mainly from Bankscope database compiled by Bureau van Dijk. Lending Rates are collected from Reserve Bank of Australia's (RBA) Indicator Lending Rates statistics and one-year term deposit rate is considered as the borrowing rate which is collected from RBA's retail deposit rate and investment rates statistics. Basel II is a dummy variable which has a value of 1 in post-Basel II period i.e., after January, 2008 and value of 0 in the pre-Basel II period i.e., before January, 2008. *,**, and *** denote $10 \%, 5 \%$, and $1 \%$ significance levels, respectively. The sample covers the annual data from 2000to 2010. 


\begin{tabular}{lll}
\hline Asset & Government & Mortgages \\
$\Delta \log \left(A_{i, t+1}\right)$ & Securities & \\
Sample & Domestic & Domestic \\
No. of Obs. & 70 & 77 \\
\hline Constant & 0.7818 & 0.2294 \\
& $(0.7863)$ & $(0.7972)$ \\
Basel II & -1.2483 & 0.3230 \\
& $(-0.8393)$ & $(0.7465)$ \\
$\Delta \log \left(A_{i, t}\right)$ & -0.0903 & -0.0771 \\
$r_{t}^{L}-r_{t}^{D}$ & $(-0.7426)$ & $(-0.6291)$ \\
$\Delta \log \left(\mathrm{GDP}_{\mathrm{t}}\right)$ & 0.2786 & -0.0542 \\
& $(1.4119)$ & $(-1.500)$ \\
$\log (\mathrm{T} 1 \mathrm{CR}, \mathrm{t})$ & -8.5193 & -0.7135 \\
$\log (\mathrm{T} 1 \mathrm{CR}, \mathrm{i},)^{*}$ Basel II & $(-1.100)$ & $(-0.4529)$ \\
& -0.4178 & 0.0507 \\
\hline $5.2 .3 \mathrm{~T}$ & $(-1.2225)$ & $(0.4296)$ \\
\hline
\end{tabular}

\subsubsection{Total Asset}

Table 8 shows the sensitivity of total assets to regulatory tier 1 capital ratio in the pre-Basel II and post-Basel II period for both domestic and international banks. The post-Basel II dummy variable, Basel II, is not statistically significant for domestic and international banks holdings of total assets indicating no change in the growth of total assets in the post-Basel II period. The tier 1 capital ratio becomes statistically insignificant for both the domestic and international banks' holdings of total assets in both the pre-Basel II and post-Basel II period. This suggests that the growth of total assets is not influenced by the regulatory changes of Basel I and Basel II.

Table: 8 Sensitivity of total assets to tier 1 capital ratio

This table reports the estimation results from the following regression models (see equation 4):

$\Delta \log \left(\mathrm{A}_{\mathrm{i}, \mathrm{t}+1}\right)=\delta_{1}+\delta_{2} \Delta \log \left(\mathrm{A}_{\mathrm{i}, \mathrm{t}}\right)+\delta_{3}\left(r_{t}^{L}-r_{t}^{D}\right)+\delta_{4} \Delta \log \left(\mathrm{GDP} P_{\mathrm{t}}\right)+\delta_{5} \log \left(\mathrm{T}_{\left.1 \mathrm{CR}_{\mathrm{i}, \mathrm{t}}\right)}\right)+\delta_{6} \log \left(\mathrm{T}_{1 C \mathrm{C}_{\mathrm{i}, \mathrm{t}}}\right) *$ Basel II + $\delta_{7}$ Basel II $+u_{\mathrm{i}, t+1}$

where, $A_{t}$ refer to Total Asset. $\mathrm{r}^{\mathrm{L}}$ refer to Interest rate on loan, $\mathrm{r}^{\mathrm{D}}$ refer to Interest rate on deposit, GDP refer to Gross domestic product, T1CR refer to Tier 1 Capital Ratio. Balance Sheet data of individual Banks have been collected mainly from Bankscope database compiled by Bureau van Dijk. Lending Rates are collected from Reserve Bank of Australia's (RBA) Indicator Lending Rates statistics and one-year term deposit rate is considered as the borrowing rate which is collected from RBA's retail deposit rate and investment rates statistics. Basel II is a dummy variable which has a value of 1 in post-Basel II period i.e., after January, 2008 and value of 0 in the preBasel II period i.e., before January, 2008.*,**, and *** denote $10 \%, 5 \%$, and $1 \%$ significance levels, respectively. The sample covers the annual data from 2000to 2010. 


\begin{tabular}{lll}
\hline Asset & Total Assets & \\
$\Delta \log \left(A_{i, t+1}\right)$ & & \\
Sample & Domestic & Intl. \\
No. of Obs. & 111 & 29 \\
\hline Constant & -0.0008 & 0.0099 \\
& $(-0.0031)$ & $(0.3251)$ \\
Basel II & 0.1649 & -0.1303 \\
& $(0.4265)$ & $(-0.3933)$ \\
$\Delta \log \left(A_{i, t}\right)$ & $0.2521^{* *}$ & -0.0509 \\
& $(2.3431)$ & $(-0.2953)$ \\
$r_{t}^{L}-r_{t}^{D}$ & $-0.0918^{* *}$ & -0.0155 \\
& $(-2.3046)$ & $(-0.3113)$ \\
$\Delta \log \left(\mathrm{GDP}_{\mathrm{t}}\right)$ & 1.4107 & 1.1171 \\
& $(0.6810)$ & $(0.8427)$ \\
$\log \left(\mathrm{T}_{\left.1 C \mathrm{CR}_{\mathrm{i}, t}\right)}\right.$ & 0.1062 & 0.0546 \\
& $(1.2175)$ & $(0.6395)$ \\
$\log \left(\mathrm{T} 1 C R_{\mathrm{i}, t}\right) *$ Basel II & -0.1325 & 0.0066 \\
& $(-0.7373)$ & $(0.0584)$ \\
\hline
\end{tabular}

\subsubsection{Liability}

The sensitivity of equity and subordinated debt to regulatory tier 1 capital ratio during the pre-Basel II and postBasel II period for both domestic and international banks are shown in Table 9. The post-Basel II dummy variable, Basel II, is not statistically significant for domestic and international banks' holdings of equity and subordinated debt, which means that there is no change in the growth of equity and subordinated debt in the post-Basel II period. In the pre-Basel II period tier 1 capital ratio becomes statistically significant and positive for equity and subordinated debt of domestic banks. This means that the slower growth of equity and subordinated debt of domestic banks are caused by the regulatory changes of Basel I. In the post-Basel II period tier 1 capital ratio however becomes statistically significant and negative for the domestic banks' holdings of subordinated debt. Such outcome can be identified as that the higher growth of subordinated debt in the post-Basel II period are influenced by the regulatory changes of Basel II. Therefore, in order to support the growth of risk-weighted assets domestic banks are issuing more subordinated debt to maintain the capital ratio because of the regulatory changes caused by Basel II.

\section{Table: 9 Sensitivity of liabilities to tier 1 capital ratio}

This table reports the estimation results from the following regression models (see equation 4):

$\Delta \log \left(\mathrm{A}_{\mathrm{i}, t+1}\right)=\delta_{1}+\delta_{2} \Delta \log \left(\mathrm{A}_{\mathrm{i}, \mathrm{t}}\right)+\delta_{3}\left(r_{t}^{L}-r_{t}^{D}\right)+\delta_{4} \Delta \log (\mathrm{GDP} \mathrm{t})+\delta_{5} \log \left(\mathrm{T}_{\left.1 \mathrm{CR}_{\mathrm{i}, \mathrm{t}}\right)}+\delta_{6} \log \left(\mathrm{T}_{1 \mathrm{CR}} \mathrm{i}, \mathrm{t}\right)\right.$ Basel II + $\delta_{7}$ Basel II $+u_{\mathrm{i}, t+1}$

where, $A_{t}$ refer to Equity and Subordinated Debt. $\mathrm{r}^{\mathrm{L}}$ refer to Interest rate on loan, $\mathrm{r}^{\mathrm{D}}$ refer to Interest rate on deposit, GDP refer to Gross domestic product, T1CR refer to Tier 1 Capital Ratio. Balance Sheet data of individual Banks have been collected mainly from Bankscope database compiled by Bureau van Dijk. Lending Rates are collected from Reserve Bank of Australia's (RBA) Indicator Lending Rates statistics and one-year term deposit rate is considered as the borrowing rate which is collected from RBA's retail deposit rate and investment rates statistics. Basel II is a dummy variable which has a value of 1 in post-Basel II period i.e., after January, 2008 and value of 0 in the pre-Basel II period i.e., before January, 2008.*,**, and *** denote $10 \%, 5 \%$, and $1 \%$ significance levels, respectively. The sample covers the annual data from 2000to 2010. 


\begin{tabular}{|c|c|c|c|c|}
\hline Liability & \multicolumn{2}{|l|}{ Equity } & \multicolumn{2}{|c|}{ Subordinated Debt } \\
\hline Sample & Domestic & Intl. & Domestic & Intl. \\
\hline No. of Obs. & 111 & 29 & 108 & 12 \\
\hline Constant & $\begin{array}{l}-0.4491 \\
(-1.4994)\end{array}$ & $\begin{array}{l}0.1644 \\
(0.7398)\end{array}$ & $\begin{array}{l}-0.0938 \\
(-0.2579)\end{array}$ & $\begin{array}{l}0.6254 \\
(0.1857)\end{array}$ \\
\hline Basel II & $\begin{array}{l}0.3703 \\
(0.8361)\end{array}$ & $\begin{array}{l}0.0125 \\
(0.0530)\end{array}$ & $\begin{array}{l}0.7410 \\
(1.4140)\end{array}$ & $\begin{array}{l}1.7316 \\
(0.6602)\end{array}$ \\
\hline$\Delta \log \left(A_{i, t}\right)$ & $\begin{array}{l}-0.0939 \\
(-0.9414)\end{array}$ & $\begin{array}{l}0.1394 \\
(0.6561)\end{array}$ & $\begin{array}{l}-0.2463 * * * \\
(-2.6453)\end{array}$ & $\begin{array}{l}-0.5524 \\
(-0.6663)\end{array}$ \\
\hline$r_{t}^{L}-r_{t}^{D}$ & $\begin{array}{l}0.0014 \\
(0.0302)\end{array}$ & $\begin{array}{l}0.0219 \\
(0.6429)\end{array}$ & $\begin{array}{l}-0.1008 * \\
(-1.8467)\end{array}$ & $\begin{array}{l}-0.1525 \\
(-0.5753)\end{array}$ \\
\hline$\Delta \log \left(\mathrm{G} D P_{\mathrm{t}}\right)$ & $\begin{array}{l}2.6761 \\
(1.1238)\end{array}$ & $\begin{array}{l}-0.5534 \\
(-0.6117)\end{array}$ & $\begin{array}{l}-4.3691 \\
(-1.5592)\end{array}$ & $\begin{array}{l}-3.8263 \\
(-0.1153)\end{array}$ \\
\hline $\log \left(\mathrm{T} 1 \mathrm{CR}_{\mathrm{i}, \mathrm{t}}\right)$ & $\begin{array}{l}0.1998 * * \\
(2.0030)\end{array}$ & $\begin{array}{l}-0.0249 \\
(-0.4124)\end{array}$ & $\begin{array}{l}0.3816 * * * \\
(3.0182)\end{array}$ & $\begin{array}{l}-0.0257 \\
(-0.0295)\end{array}$ \\
\hline $\log \left(\mathrm{T} 1 \mathrm{CR}_{\mathrm{i}, \mathrm{t}}\right) *$ Basel II & $\begin{array}{l}-0.1630 \\
(-0.7913)\end{array}$ & $\begin{array}{l}-0.0179 \\
(-0.2240)\end{array}$ & $\begin{array}{l}-0.4245^{*} \\
(-1.7315)\end{array}$ & $\begin{array}{l}-0.6942 \\
(-0.6045)\end{array}$ \\
\hline
\end{tabular}

\section{Robustness Check}

Robustness of these results has been checked by identifying whether the behaviour of the Australian banks change in anticipation of the implementation of Basel II in earlier period such as January, 2006. To check the robustness, it is tested that whether banks start to adjust their asset portfolios from January, 2006 with an expectation to the implementation of Basel II. The reason for choosing the year 2006 is that the final rules of Basel II were developed on November, 2005. In the robustness check, the effect of Basel II is tested from 2006. A dummy variable, post_06, is considered which has a value of 1 from January, 2006 and onwards and value of 0 before January, 2006. The results indicate that the growth of net loans of domestic banks is significantly higher after 2006 with respect to total capital ratio. In addition, the higher growth of net loans of domestic banks after 2006 with respect to total capital ratio is influenced by the regulatory changes of Basel II. The results also indicate that the growth of subordinated debt of domestic banks is significantly higher after 2006 with respect to both total capital ratio and tier 1 capital ratio. Again, the higher growth of subordinated debt of domestic banks after 2006 with respect to both total capital ratio and tier 1 capital ratio are influenced by the regulatory changes of Basel II. However, the slower growth of subordinate debt of domestic banks before 2006 with respect to both total capital ratio and tier 1 capital ratio are caused by the regulatory changes of Basel I. There is no change in the growth of low-risk asset and total assets after 2006 and these are not affected by Basel II as well. Therefore, the robustness check confirms that the growth of high-risk weighted assets is higher in post-Basel II period and Basel II affects it. In addition, banks issue more subordinate debt in the post-Basel II period to maintain capital ratio. Therefore, we can infer that Basel II has started to affect banks' portfolio decision from 2006 and the robustness check supports the findings of the study.

\section{Limitation and Further Research Implications}

One potential limitation of the study is that limited data of foreign banks as the foreign subsidiary banks do not publish annual reports. Therefore, data of foreign banks that are missing cannot be collected. The number of banks operating in Australia is relatively small and the majority of the banking activities are captured by the four major banks named Australia and New Zealand Banking Group, Commonwealth Bank of Australia, National Australia Bank Limited and Westpac Banking Corporation. This feature of Australian banks may affect the analysis of this paper.

Future research could be performed by using the data of risk-weighted assets considering the credit rating of counter parties of each asset category. However, data availability may be a wishful thought.

\section{Conclusion}

This paper has been the first attempt to identify the sensitivity of various risk-weighted assets and liabilities to total regularity capital and core regulatory capital after the implementation of Basel II on Australian banks. The analysis of this paper show that the growth of total assets does not change in the post-Basel II period and the growth of total assets are not influenced by Basel II. Therefore, this research rejects the capital crunch hypothesis 
of shrinkage of the assets of banks induced by the stricter capital requirement in the post-Basel II period in Australia. However, this paper finds that the shrinkage of total assets in the pre-Basel II period is caused by the regulatory changes come with Basel I with respect to the regulatory total capital ratio. The findings of this paper also show that in the post-Basel II period, Australian banks face higher growth of non-residential loans and equity investments and the higher growth of these assets are caused by the regulatory changes of Basel II. Therefore, this paper does not find the evidence of credit crunch hypothesis in the post-Basel II period in Australia, which assumes that stricter capital requirement induces banks to reduce their loan supply.

However, there is no change in the growth of low-risk assets such as mortgages and government securities and Basel II does not cause the growth in the post-Basel II period. Therefore, this paper infers that the rigorous capital regulation originated by Basel II do not provide an incentive for banks to expand the investment in lowrisk assets and to curtail the investment in high-risk assets in Australia. Another finding is that, in the post-Basel II period, the banks have issued more subordinated debt to maintain the capital ratio with respect to regulatory Tier 1 capital ratio. Nevertheless, in the pre-Basel II period, the slower growth of equity and subordinated debt is caused by Basel I. The robustness check shows that banks have started to change their asset portfolio from 2006 with an expectation to the implementation of Basel II. This paper supports that Australian banks are very well capitalized and financially sound because the stricter capital regulation does not force them to reduce total assets and loan supply. It is expected that these findings could help policy makers to set up Basel III more accurately so that the possibilities of banking failures and financial crises in Australia do not exist.

\section{References}

BEATTY, A. L. \& GRON, A. 2001. Capital, portfolio, and growth: bank behavior under risk-based capital guidelines. Journal of Financial Services Research, 20, 5-31.

BERGER, A. N. \& UDELL, G. F. 1994. Do risk-based capital allocate bank credit and cause a 'Credit Crunch" in the United States? Journal of Money, Credit and Banking, 26, 585-628.

BLASKO, M. \& SINKEY, J. J. F. 2006. Bank asset structure, real-estate lending, and risk-taking. Quarterly Review of Economics and Finance, 46, 53-81.

BRANA, S. \& LAHET, D. 2009. Capital requirement and financial crisis: the case of Japan and the 1997 Asian crisis. Japan and the World Economy, 21, 97-104.

BRINKMANN, E. J. \& HORVITZ, P. M. 1995a. Risk-Based Capital Standards and the Credit Crunch. Journal of Money, Credit and Banking, 27, 848-863.

BRINKMANN, E. J. \& HORVITZ, P. M. 1995b. Risk-based capital standards and the credit crunch. Journal of Money, Credit \& Banking (Ohio State University Press), 27, 848-863.

DAVIS, K. 2005. Basel II : the new Basel accord is an important step in the regulation and supervision of banking markets with significant implications for the development of financial markets and the competitive positions of banks Journal of Banking and Financial Services, 119, 7-9.

DAVIS, K. 2011. Basel III liquidity options. Australian Centre for Financial Studies, FRDP 2011-02.

GAMBACORTA, L. \& MISTRULLI, P. E. 2004. Does bank capital affect lending behavior? Journal of Financial Intermediation, 13, 436-457.

HALL, B. J. 1993. How Has the Basle Accord Affected Bank Portfolios? Journal of the Japanese and International Economies, 7, 408-440.

HAWTREY, K. 2009. The global credit crisis: why have Australian banks been so remarkably resilient? Agenda: A Journal of Policy Analysis and Reform, 16, 95-114.

HEID, F. 2007. The cyclical effects of the Basel II capital requirements. Journal of Banking \& Finance, 31, $3885-$ 3900.

HOGAN, W. P. \& SHARPE, I. G. 1990. Risk-based capital adequacy of Australian banks. Australian Journal of Management, 15, 177.

HORIUCHI, A. \& SHIMIZU, K. 1998. The deterioration of bank balance sheets in Japan: risk-taking and recapitalization. Pacific-Basin Finance Journal, 6, 1-26.

HYUN, J.-S. \& RHEE, B.-K. 2011. Bank capital regulation and credit supply. Journal of Banking \& Finance, 35 , 323-330.

ITO, T. \& SASAKI, Y. N. 2002. Impacts of the Basle capital standard on Japanese banks' behavior. Journal of the Japanese and International Economies, 16, 372-397.

JACQUES, K. T. 2008. Capital shocks, bank asset allocation, and the revised Basel Accord. Review of Financial Economics, 17, 79-91.

KISHAN, R. P. \& OPIELA, T. P. 2006. Bank capital and loan asymmetry in the transmission of monetary policy. Journal of Banking \& Finance, 30, 259-285.

MEMMEL, C. \& RAUPACH, P. 2010. How do banks adjust their capital ratios? Journal of Financial Intermediation, 19, 509-528.

MONTGOMERY, H. 2005. The effect of the Basel Accord on bank portfolios in Japan. Journal of the Japanese 
and International Economies, 19, 24-36.

MYERS, S. C. \& MAJLUF, N. S. 1984. Corporate financing and investment decisions when firms have information that investors do not have. Journal of Financial Economics, 13, 187-221.

PEEK, J. \& ROSENGREN, E. 1995a. Bank regulation and the credit crunch. Journal of Banking \& Finance, 19, 679-692.

PEEK, J. \& ROSENGREN, E. 1995b. The capital crunch: neither a borrower nor a lender be. Journal of Money, Credit and Banking, 27, 625-638.

REPULLO, R. \& SUAREZ, J. 2004. Loan pricing under Basel capital requirements. Journal of Financial Intermediation, 13, 496-521.

SIMONE, V. 2011. Liquidity risk, credit risk, market risk and bank capital. International Journal of Managerial Finance, 7, 134-152.

STEFAN, S. 2011. Basel III's ability to mitigate systemic risk. Journal of Financial Regulation and Compliance, $19,337-354$.

WATANABE, W. 2007. Prudential regulation and the "credit crunch": evidence from Japan. Journal of Money, Credit and Banking, 39, 639-665.

ZICCHINO, L. 2006. A model of bank capital, lending and the macroeconomy: Basel I versus Basel II. Manchester School, 74, 50-77.

\begin{tabular}{cl} 
& \multicolumn{1}{c}{$\begin{array}{c}\text { Appendices } \\
\text { Appendix A }\end{array}$} \\
List of Local Australian Banks \\
No. & Name of the Bank \\
\hline 1 & Adelaide Bank Ltd. \\
2 & AMP Bank Limited \\
3 & Australia and New Zealand Banking Group \\
4 & Bank of Queensland Limited \\
5 & Bank of Western Australia Limited \\
6 & Bendigo and Adelaide Bank Limited \\
7 & Commonwealth Bank of Australia \\
8 & Macquarie Bank Ltd \\
9 & Members Equity Bank Pty Ltd \\
10 & National Australia Bank Limited \\
11 & Rural Bank Limited \\
12 & St. George Bank Limited \\
13 & Suncorp-Metway Ltd \\
14 & Westpac Banking Corporation \\
\hline &
\end{tabular}

